

p-ISSN: 2621-1203 | https://doi.org/10.32665/james.v4i1.178

e-ISSN: 2621-1211

\title{
CONFIRMATORY FACTOR ANALYSIS UNTUK MENGUKUR PERTUMBUHAN PENDUDUK DI KABUPATEN BOJONEGORO
}

\author{
Moch Nur Faizin ${ }^{1}$, Alif Yuanita Kartini \\ Universitas Nahdlatul Ulama Sunan Giri, cheeffaizin@ gmail.com ${ }^{1}$ \\ Universitas Nahdlatul Ulama Sunan Giri,_yuanitaalif5@gmail.com² \\ Received : 27 April 2021, Revised : 29 April 2021, Accepted : 29 April 2021 \\ (C) Mathematics Education Unugiri 2021
}

\begin{abstract}
Population growth is closely related to the addition and or reduction of the population in a specific area. Many factors influence population growth in an area, including births, deaths, and population movements. The development of the population of Bojonegoro Regency until 2020 has increased every year. The population development in Bojonegoro Regency has increased by 0.96 percent, which is thought to be caused by births, migration, and economic growth. In this study, to measure population growth in Bojonegoro Regency, this study conducted confirmation or testing to determine how well the measured variables represented the factors formed using the confirmatory factor analysis (CFA) method. The results showed that the characteristics of population growth in the Bojonegoro Regency were influenced by three latent variables, including fertility, mortality, and migration. In contrast, the most dominant variables in influencing population growth were total births, live birth rates, female child ratio, and life expectancy: infant mortality rates, under-five mortality rates, out-migration, and gross migration.
\end{abstract}

Keywords : CFA, Population Growth, Bojonegoro

\begin{abstract}
Abstrak
Pertumbuhan penduduk erat kaitanya dengan penambahan dan atau pengurangan jumlah penduduk di suatu wilayah tertentu. Banyak factor yang mempengaruhi pertumbuhan penduduk di suatu wilayah diantaranya kelahiran, kematian dan perpindahan penduduk. Perkembangan jumlah penduduk Kabupaten Bojonegoro hingga tahun 2020 mengalami kenaikan setiap tahun. Perkembangan penduduk di Kabupaten Bojonegoro mengalami pertambahan sebesar 0,96 persen yang diduga disebabkan oleh kelahiran, migrasi dan pertumbuhan ekonomi. Untuk mengukur pertumbuhan penduduk di Kabupaten Bojonegoro, pada penelitian ini dilakukan konfirmasi atau pengujian untuk mengetahui seberapa baik variabel yang telah diukur dapat mewakili faktor yang terbentuk menggunakan metode confirmatory factor analysis (CFA). Hasil penelitian menunjukkan bahwa pada karakteristik pertumbuhan penduduk di Kabupaten Bojonegoro dipengaruhi oleh tiga variabel laten diantaranya yaitu fertilitas, mortalitas, dan migrasi, sementara variabel yang paling dominan dalam mempengaruhi pertumbuhan penduduk adalah jumlah kelahiran total, angka lahir hidup, rasio anak wanita, angka harapan hidup, angka kematian bayi, angka angka kematian balita, migrasi keluar, dan migrasi bruto.
\end{abstract}

Kata Kunci : CFA, Pertumbuhan Penduduk, Bojonegoro

\section{Pendahuluan}

Pertumbuhan penduduk erat kaitannya dengan penambahan dan atau pengurangan jumlah penduduk di suatu wilayah tertentu. Pertumbuhan penduduk akan berdampak pada perkembangan ekonomi suatu negara. Jika pertumbuhan penduduk tinggi maka juga akan berdampak pada masalah ekonomi, demikian juga sebaliknya apabila pertumbuhan penduduk rendah juga akan berdampak pada masalah ekonomi. Sehingga untuk mengatasi masalah ekonomi suatu negara salah satunya yaitu 
dengan cara mengendalikan pertumbuhan penduduknya. Banyak factor yang mempengaruhi pertumbuhan penduduk di suatu wilayah diantaranya adalah kelahiran, kematian serta perpindahan penduduk dari satu wilayah ke wilayah yang lain [1]. Kelahiran dan perpindahan penduduk masuk ke wilayah tertentu akan menyebabkan jumlah penduduk bertambah, sedangkan kematian dan perpindahan penduduk keluar akan menyebabkan jumlah penduduk berkurang. Adanya perbaikan pelayanan Kesehatan akan mengakibatkan jumlah kematian yang rendah, sedangkan laju tingkat kelahiran tetap tinggi. Hal inilah yang merupakan salah satu penyebab utama masalah ledakan penduduk [2]. Untuk menekan laju pertumbuhan penduduk terutama untuk mencegah ledakan jumlah penduduk diperlukan program keluarga berencana yang menjadi salah satu cara yang dilakukan. Selain itu program keluarga berencana merupakan kebutuhan utama keluarga untuk membentuk keluarga kecil yang Bahagia dan sejahtera.

Bojonegoro merupakan salah satu kabupaten yang ada di Jawa Timur. Jumlah penduduk kabupaten Bojonegoro tahun 2020 yaitu sebesar 1.344.038 jiwa sedangkan pada tahun 2019 yaitu sebesar 1.331.077 jiwa. Jika dibandingkan jumlah penduduk antara tahun 2020 dengan tahun sebelumnya makamengalami kenaikan sebesar 12.961 jiwa dalam kurun waktu 1 tahun. Sehingga pertambahan penduduk di Kabupaten Bojonegoro sebesar 0,96 persen [3]. Dengan meningkatnya jumlah penduduk dimungkinkan jumlah penduduk miskin juga mengalami kenaikkan dan akan memunculkan berbagai masalah diantaranya tingkat kriminalitas meningkat, jumlah pengangguran semakin banyak, tingkat kesejahteraan masyarakat berkurang dan lain sebagainya. Untuk itu perlu dilakukan suatu penelitian tentang factor yang mempengaruhi pertumbuhan penduduk di Kabupaten Bojonegoro sehingga nantinya bisa memberikan masukan kepada pemerintah untuk membuat suatu kebijakan yang berkaitan dengan upaya untuk menekan jumlah pertumbuhan penduduk khususnya di Kabupaten Bojonegoro.

Sebelumnya telah dilakukan penelitian tentang pertumbuhan penduduk yaitu "Analisis Faktor-faktor yang mempengaruhi pertumbuhan penduduk di kota Pekanbaru". Metode analisis yang digunakan dalam penelitian tersebut adalah regresi logaritmalinier berganda. Salah satu metode analisis lain yang bisa digunakan untuk mengetahui factorfaktor yang mempengaruhi pertumbuhan penduduk adalah Confirmatory Factor Analysis (CFA) [4]. CFA merupakan metode yang digunakan untuk menguji suatu variabel yang akan digunakan yang bisa mewakili factor yang terbentuk sebelumnya [5]. Oleh karena itu dalam penelitian ini ingin mengetahui bagaimana karakteristik pertumbuhan penduduk di Kabupaten Bojonegoro pada masing-masing kecamatan dan indicator apa yang paling dominan membangun factor pertumbuhan penduduk di Kabupaten Bojonegoro.

\section{Metode Penelitian}

\subsection{Sumber Data}

Data yang digunakan dalam penelitian ini adalah data sekunder dari Profil Kesehatan Kabupaten Bojonegoro tahun 2018 dan Profil Daerah Kabupaten Bojonegoro tahun 2018 [6].

\subsection{Variabel Penelitian}

Variabel-variabel penelitian yang digunakan antara lain tiga variabel laten yakni Fertilitas, Mortalitas dan Migrasi, dengan 12 variabel indikator (manifest) yaitu anak lahir hidup (X1), rasio anak wanita (X2), angka kelahiran total (X3), angka prevalensi pemakaian kontrasepsi (X4), angka harapan hidup (X5), angka kematian bayi (X6), angka kematian balita (X7), maternal mortality (X8), migrasi masuk (X9), migrasi keluar (X10), migrasi neto (X11) dan migrasi bruto (X12).

\subsection{Langkah-langkah Analisis Data}

Adapun Langkah-langkah analisis dalam penelitian ini adalah sebagai berikut. 
a. Mendeskripsikan setiap variabel indicator untuk mengetahui karakteristiknya.

b. Melakukan evaluasi pada indicator penilaian yang berpengaruh signifikan terhadap variabel laten dengan tahapan :

1) Melakukan pengujian asumsi distribusi normal multivariat yang diharapkan berdistribusi normal multivariate

2) Identifikasi model yang diharapkan adalah model over identified

3) Melakukan uji kebaikan model dengan kriteria Goodness of Fits dan apabila belum sesuai maka dilakukan modifikasi model

4) Melakukan uji signifikansi untuk masing-masing parameter variabel laten dengan kriteria apabila nilai p_value kurang dari $\alpha=0,05$ maka variabel tersebut signifikan membentuk unidimensi [7].

5) Melakukan uji validitas dan reliabiltas untuk masing-masing unidimensional. Hal ini untuk mengetahui sejauh mana konstruk mampu menjelaskan secara representative dan konsisten terhadap variabelnya [8].

Menginterpretasikan hasil analisis data dengan menggunakan metode CFA dengan bantuan software lisrel 10.3.

\section{Pembahasan}

\subsection{Karakteristik Penduduk di Kabupaten Bojonegoro}

Tabel 1. Karakteristik Penduduk di Kabupaten Bojonegoro tahun 2018

\begin{tabular}{cccrrr}
\hline $\begin{array}{c}\text { Variabel } \\
\text { Laten }\end{array}$ & $\begin{array}{c}\text { Indi- } \\
\text { kator }\end{array}$ & Mean & \multicolumn{1}{c}{ Min } & \multicolumn{1}{c}{ Max } & Std. Dev \\
\hline \multirow{4}{*}{ Fertilitas } & $\mathrm{X}_{1}$ & 613.36 & 141 & 1173 & 302.194 \\
& $\mathrm{X}_{2}$ & 296.39 & 69 & 587 & 148.505 \\
& $\mathrm{X}_{3}$ & 618.36 & 141 & 1182 & 304.588 \\
& $\mathrm{X}_{4}$ & 870.704 & 556.54 & 2023.42 & 314.36818 \\
\hline \multirow{4}{*}{ Mortalitas } & $\mathrm{X}_{5}$ & 4.64 & 0 & 9 & 2.738 \\
& $\mathrm{X}_{6}$ & 6.00 & 0 & 11 & 3.600 \\
& $\mathrm{X}_{7}$ & 6.50 & 0 & 12 & 3.883 \\
& $\mathrm{X}_{8}$ & .25 & 0 & 2 & .518 \\
\hline \multirow{4}{*}{ Migrasi } & $\mathrm{X}_{9}$ & 120.54 & 7 & 741 & 151.948 \\
& $\mathrm{X}_{10}$ & 113.64 & 11 & 685 & 136.690 \\
& $\mathrm{X}_{11}$ & 26.89 & 1 & 103 & 25.743 \\
& $\mathrm{X}_{12}$ & 234.18 & 23 & 1426 & 286.673 \\
\hline
\end{tabular}

http://journal.unugiri.ac.id/index.php/JaMES
Uraian untuk mengetahui informasi yang dapat diperoleh dari karakteristik penduduk di Kabupaten Bojonegoro pada setiap Kecamatan dapat diketahui melalui analisis statistika deskriptif, dengan melihat nilai rata-rata dan standar deviasi setiap indikator yang membentuk variabel laten fertilitas, mortalitas, migrasi. Tabel 1 menunjukkan hasil statistika deskrptif pada karakteristik penduduk di kabupaten Bojonegoro.

Dari hasil output diatas dapat diketahui bahwa karakteristik penduduk di kabupaten bojonegoro pada tahun 2018 dipengaruhi oleh 3 variabel laten yaitu fertilitas, mortalitas dan migrasi. Variabel fertilitas dipengaruhi oleh 4 indikator diantaranya angka kelahiran hidup $\left(\mathrm{X}_{1}\right)$, rasio anak wanita $\left(\mathrm{X}_{2}\right)$, angka kelahiran total $\left(\mathrm{X}_{3}\right)$, angka prevelensi pemakaian kontrasepsi $\left(\mathrm{X}_{4}\right)$. Angka kelahiran hidup $\left(\mathrm{X}_{1}\right)$ di kabupaten bojonegoro rata-rata adalah 613,36 atau 613 anak pada tahun 2018, sementara untuk angka kelahiran hidup terendah terdapat pada kecamatan ngambon yaitu 141 anak, sedangkan angka kelahiran hidup tertinggi di kecamatan baureno sebanyak 1173 anak pada tahun 2018 dengan standar deviasi sebesar 302,194. Rasio anak wanita $\left(\mathrm{X}_{2}\right)$ di kabupaten bojonegoro rata-rata adalah 296,39 atau 629 anak pada tahun 2018, sementara untuk rasio anak wanita terendah terdapat pada kecamatan ngambon yaitu 69 anak, sedangkan rasio anak wanita tertinggi di kecamatan dander sebanyak 587 anak pada tahun 2018 dengan standar deviasi sebesar 148 505. Angka kelahiran total $\left(\mathrm{X}_{3}\right)$ di kabupaten bojonegoro rata-rata adalah 618,36 atau 618 anak pada tahun 2018, sementara untuk angka kelahiran total terendah terdapat pada kecamatan ngambon yaitu 141 anak, sedangkan angka kelahiran total tertinggi di kecamatan baureno sebanyak 1182 anak pada tahun 2018 dengan standar deviasi sebesar 304,588. Angka prevelensi pemakaian kontrasepsi $\left(\mathrm{X}_{4}\right)$ di kabupaten bojonegoro ratarata adalah 870,7043 atau 871 anak pada tahun 2018, sementara untuk angka prevelensi pemakaian kontrasepsi terendah terdapat pada kecamatan ngambon yaitu 556,54 atau 557 
anak, sedangkan angka prevelensi pemakaian kontrasepsi tertinggi di kecamatan Sugihwaras sebanyak 2023,41 atau 2023 anak pada tahun 2018 dengan standar deviasi sebesar 314,36818.

Variabel mortalitas dipengaruhi oleh 4 indikator diantaranya angka harapan hidup $\left(\mathrm{X}_{5}\right)$, angka kematian bayi $\left(\mathrm{X}_{6}\right)$, angka kematian balita $\left(\mathrm{X}_{7}\right)$, maternal mortality $\left(\mathrm{X}_{8}\right)$. Angka harapan hidup $\left(\mathrm{X}_{5}\right)$ di kabupaten bojonegoro rata-rata adalah 4,64 atau 5 orang pada tahun 2018, sementara untuk angka harapan hidup terendah terdapat pada kecamatan bubulan,kasiman yaitu 0 orang, sedangkan angka prevelensi pemakaian kontrasepsi tertinggi di kecamatan bojonegoro sebanyak 9 orang pada tahun 2018 dengan standar deviasi sebesar 2,738. Angka kematian bayi $\left(\mathrm{X}_{6}\right)$ di kabupaten bojonegoro rata-rata adalah 6 anak pada tahun 2018, sementara untuk angka kematian bayi terendah terdapat pada kecamatan kasiman yaitu 0 anak, sedangkan angka kematian bayi tertinggi di kecamatan kepohbaru, kapas, kalitidu sebanyak 11 anak pada tahun 2018 dengan standar deviasi sebesar 3,600 . Angka kematian balita $\left(\mathrm{X}_{7}\right)$ di kabupaten bojonegoro rata-rata adalah 6,50 atau 7 anak pada tahun 2018, sementara untuk angka kematian balita terendah terdapat pada kecamatan kasiman yaitu 0 anak, sedangkan angka kematian balita tertinggi di kecamatan kepohbaru sebanyak 12 anak pada tahun 2018 dengan standar deviasi sebesar 3,883. Maternal mortality $\left(\mathrm{X}_{8}\right)$ di kabupaten bojonegoro ratarata adalah 25 orang pada tahun 2018, sementara untuk maternal mortality terendah terdapat pada kecamatan margomulyo, ngraho, tambakrejo, ngambon, sekar, bubulan, gondang, temayang, sugihwaras, kepohbaru, baureno, kanor, sumberejo, balen, bojonegoro, trucuk, dander, kalitidu, malo, purwosari, kasiman, kedawen yaitu 0 orang, sedangkan maternal mortality tertinggi di kecamatan sukosewu sebanyak 2 orang pada tahun 2018 dengan standar deviasi sebesar 0,518.

Variabel migrasi dipengaruhi oleh 4 indikator diantaranya migrasi masuk $\left(X_{9}\right)$, migrasi keluar $\left(\mathrm{X}_{10}\right)$, migrasi neto $\left(\mathrm{X}_{11}\right)$, migrasi bruto $\left(\mathrm{X}_{12}\right)$. Migrasi masuk $\left(\mathrm{X}_{9}\right)$ di kabupaten bojonegoro rata-rata adalah 120,54 atau 121 orang pada tahun 2018, sementara untuk migrasi masuk terendah terdapat pada kecamatan kedawen yaitu 7 orang, sedangkan migrasi masuk tertinggi di kecamatan trucuk sebanyak 741 orang pada tahun 2018 dengan standar deviasi sebesar 151,948. Migrasi keluar $\left(\mathrm{X}_{10}\right)$ di kabupaten bojonegoro rata-rata adalah 113,64 atau 114 orang pada tahun 2018, sementara untuk migrasi keluar terendah terdapat pada kecamatan ngambon yaitu 11 orang, sedangkan migrasi keluar tertinggi di kecamatan trucuk sebanyak 685 orang pada tahun 2018 dengan standar deviasi sebesar 136,690. Migrasi neto $\left(\mathrm{X}_{11}\right)$ di kabupaten bojonegoro rata-rata adalah 26,89 atau 27 orang pada tahun 2018, sementara untuk migrasi neto terendah terdapat pada kecamatan kasiman yaitu 1 orang, sedangkan migrasi neto tertinggi di kecamatan ngraho sebanyak 103 orang pada tahun 2018 dengan standar deviasi sebesar 25,743. Migrasi bruto $\left(\mathrm{X}_{12}\right)$ di kabupaten bojonegoro rata-rata adalah 234,18 atau 234 orang pada tahun 2018, sementara untuk migrasi bruto terendah terdapat pada kecamatan kedawen yaitu 23 orang, sedangkan migrasi bruto tertinggi di kecamatan trucuk sebanyak 1426 orang pada tahun 2018 dengan standar deviasi sebesar 268,673.

\subsection{Analisis Multivariate Normal}

Salah satu asumsi yang harus terpenuhi untuk kasus multivariate dalam CFA sebelum dilakukan tahapan analisis data yaitu harus berdistribusi normal multivariate [9]. Dalam penelitian ini tiga variabel laten yang digunakan yaitu fertilitas, mortalitas dan migrasi semua berdistribusi normal multivariate.

\subsection{Unidimensional Variabel Laten}

1. Variabel Laten Pertumbuhan Penduduk Untuk memperoleh model second order maka dilakukan trial and error dari keseluruhan indikator, sehingga diperoleh hasil yang memenuhi kriteria kebaikan model dengan menggunakan goodness of fits. Hasil 
pemodelan CFA second order pada pertumbuhan penduduk Kabupaten Bojonegoro digambarkan pada Gambar 1.

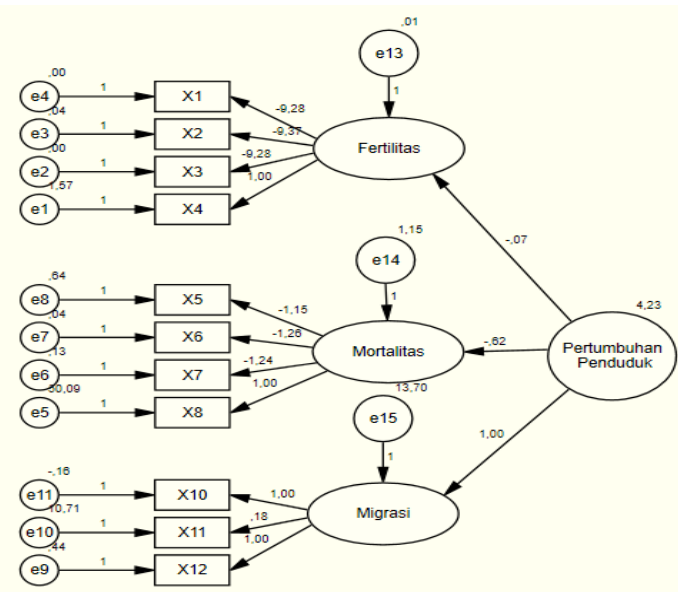

Gambar 1. Nilai Standardize Estimate Second Order Pertumbuhan Penduduk

Berdasarkan pada Gambar 1 menunjukkan bahwa nilai loading faktor paling besar terdapat pada migrasi. Hal ini berarti bahwa migrasi memiliki pengaruh terbesar terhadap pertumbuhan penduduk.

Langkah berikutnya yaitu melakukan identifikasi model.. Hasil dari identifikasi model sebagaimana ditunjukkan pada Tabel 2 berikut.

Tabel 2. Kriteria Kebaikan Model Pertumbuhan Penduduk

\begin{tabular}{cccc}
\hline Kriteria & $\begin{array}{c}\text { Cutt-of } \\
\text { value }\end{array}$ & $\begin{array}{c}\text { Hasil } \\
\text { Model }\end{array}$ & $\begin{array}{c}\text { Evaluasi } \\
\text { model }\end{array}$ \\
\hline Chi-Square & $\leq 65,17$ & 77,00 & Kurang \\
$(\mathrm{df}=28 ; 0,05)$ & & Baik \\
P-value & $\geq 0.05$ & 0.105 & Baik \\
GFI & $\geq 0.90$ & 0.965 & Baik \\
RMSEA & $\leq 0.08$ & 0.050 & Baik \\
AGFI & $\geq 0.90$ & 0.931 & Baik \\
\hline
\end{tabular}

Berdasarkan Tabel 2 terlihat bahwa sudah memenuhi kriteria kebaikan model jika dilihat dari nilai P-value, GFI, RMSE dan AGFI, sehingga dapat dilanjutkan untuk pengujian signifikan validitas indikator terhadap variabel laten. Nilai loading factor dan pengujian signifikansi untuk masing-masing indikator terhadap variabel laten sebagaimana ditunjukkan pada Tabel 3 berikut.

Tabel 3. Loading Factor Pertumbuhan Penduduk

\begin{tabular}{|c|c|c|c|}
\hline Hubungan & Estimasi & P-value & Keterangan \\
\hline $\begin{array}{c}\text { Fertilitas } \leftarrow \\
\text { Pertumbuhan } \\
\text { Penduduk }\end{array}$ & $-0,075$ & 0,049 & Signifikan \\
\hline $\begin{array}{c}\text { Migrasi } \leftarrow \\
\text { Pertumbuhan } \\
\text { Penduduk }\end{array}$ & 1,000 & 0,000 & Signifikan \\
\hline $\begin{array}{c}\text { Mortalitas } \leftarrow \\
\text { Pertumbuhan } \\
\text { Penduduk }\end{array}$ & $-0,617$ & 0,019 & Signifikan \\
\hline $\begin{array}{c}\mathrm{X} 4 \leftarrow \\
\text { Fertilitas }\end{array}$ & 0,976 & 0,440 & $\begin{array}{c}\text { Tidak } \\
\text { Signifikan }\end{array}$ \\
\hline $\begin{array}{c}\mathrm{X} 3 \leftarrow \\
\text { Fertilitas }\end{array}$ & 0,948 & 0,00 , & Signifikan \\
\hline $\begin{array}{c}\mathrm{X} 2 \leftarrow \\
\text { Fertilitas }\end{array}$ & 0,925 & 0,001 & Signifikan \\
\hline $\begin{array}{c}\mathrm{X} 1 \leftarrow \\
\text { Fertilitas }\end{array}$ & 0,900 & 0,001 & Signifikan \\
\hline $\begin{array}{c}\text { X8 } \leftarrow \\
\text { Mortalitas }\end{array}$ & 0,914 & 0,912 & $\begin{array}{c}\text { Tidak } \\
\text { Signifikan }\end{array}$ \\
\hline $\begin{array}{c}\text { X7 } \leftarrow \\
\text { Mortalitas }\end{array}$ & 0,822 & 0,001 & Signifikan \\
\hline $\begin{array}{c}\text { X6 } \leftarrow \\
\text { Mortalitas }\end{array}$ & 0,665 & 0,001 & Signifikan \\
\hline $\begin{array}{c}\text { X5 } \leftarrow \\
\text { Mortalitas }\end{array}$ & 0,580 & 0,001 & Signifikan \\
\hline $\begin{array}{l}\text { X12 } \leftarrow \\
\text { Migrasi }\end{array}$ & $-0,681$ & 0,872 & $\begin{array}{c}\text { Tidak } \\
\text { Signifikan }\end{array}$ \\
\hline $\begin{array}{l}\text { X11 } \leftarrow \\
\text { Migrasi }\end{array}$ & 0,600 & 0,001 & Signifikan \\
\hline $\begin{array}{l}\text { X10 } \leftarrow \\
\text { Migrasi }\end{array}$ & 0,635 & 0,001 & Signifikan \\
\hline $\begin{array}{c}\text { X9 } \leftarrow \\
\text { Migrasi }\end{array}$ & 0,527 & 0,516 & $\begin{array}{c}\text { Tidak } \\
\text { Signifikan }\end{array}$ \\
\hline
\end{tabular}

Berdasarkan Tabel 3 terlihat bahwa terdapat sembilan indikator yang signifikan yaitu fertilitas, mortalitas dan migrasi, $\mathrm{X}_{1}, \mathrm{X}_{2}$, $\mathrm{X}_{3}, \mathrm{X}_{5}, \mathrm{X}_{6}, \mathrm{X}_{7}, \mathrm{X}_{10}$ dan $\mathrm{X}_{11}$, yang membentuk variabel laten pertumbuhan penduduk. Hal ini dilihat dari nilai $p$-value pada masing-masing indikator yang kurang dari $\alpha=0,05$. Sehingga Langkah selanjutnya yaitu melakukan analisis dengan menggunakan first order confirmatory factor analysis (CFA) untuk mendapatkan variabel yang signifikan untuk mengukur pertumbuhan penduduk. Akan tetapi 
sebelumnya perlu diuji seberapa besar nilai reliabilitas constructnya.

Tabel 4. Perhitungan Construct Reliability Pertumbuhan Penduduk

\begin{tabular}{ccc}
\hline Hubungan & Estimasi & $\begin{array}{c}\text { Kesalahan } \\
\text { pengukuran } \\
\left(\boldsymbol{e}_{\boldsymbol{i}}=\mathbf{1}-\boldsymbol{L i}^{\mathbf{2}}\right)\end{array}$ \\
\hline Fertilitas $\leftarrow$ & & \\
Pertumbuhan & $-0,075$ & $-0,724$ \\
$\quad$ Penduduk & & \\
Migrasi $\leftarrow$ & & \\
Pertumbuhan & 1,000 & $-1,617$ \\
Penduduk & & \\
Mortalitas $\leftarrow$ & & \\
Pertumbuhan & $-0,617$ & $-1,060$ \\
Penduduk & & \\
X4 $\leftarrow$ Fertilitas & 0,976 & 9,199 \\
X3 $\leftarrow$ Fertilitas & 0,948 & 8,945 \\
X2 $\leftarrow$ Fertilitas & 0,925 & 8,199 \\
X1 $\leftarrow$ Fertilitas & 0,900 & 7,049 \\
X8 $\leftarrow$ Mortalitas & 0,914 & 6,743 \\
X7 $\leftarrow$ Mortalitas & 0,822 & 6,743 \\
X6 $\leftarrow$ Mortalitas & 0,665 & $-6,159$ \\
X5 $\leftarrow$ Mortalitas & 0,580 & 6,245 \\
X12 $\leftarrow$ Migrasi & $-0,681$ & 5,718 \\
X11 $\leftarrow$ Migrasi & 0,600 & 5,718 \\
X10 $\leftarrow$ Migrasi & 0,635 & $-5,475$ \\
Jumlah & 7,592 & 48,524 \\
\hline
\end{tabular}

Berdasarkan pada Tabel 4 didapatkan nilai construct reliability sebagai berikut :

$$
\begin{aligned}
C R=\frac{\left[\sum_{i=1}^{n} L_{i}\right]^{2}}{\left[\sum_{i=1}^{n} L_{i}\right]^{2}+\left[\sum_{i=1}^{n} L e_{2}\right]}, \\
=\frac{[48,524]^{2}}{[48,524]^{2}+[7,592]} \\
=0,997
\end{aligned}
$$

Nilai construct reliability variabel laten pertumbuhan penduduk menghasilkan nilai sebesar 0,997. Nilai tersebut lebih dari 0.7 sehingga dapat dikatakan bahwa variabel laten pertumbuhan penduduk memiliki konsistensi yang tinggi dan mampu menjelaskan secara representative terhadap variabelnya.

\section{Variabel Laten Fertilitas}

Analisis First Order CFA pada variabel laten fertilitas terdiri dari empat indikator yaitu
$\mathrm{X}_{1}, \mathrm{X}_{2}, \mathrm{X}_{3}$, dan $\mathrm{X}_{4}$, dengan hasil estimasi untuk indikator fertilitas sebagaimana ditunjukkan pada Gambar 2.

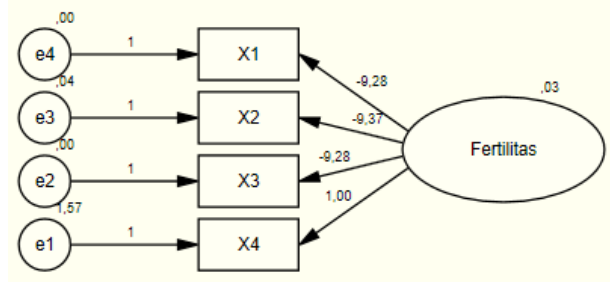

\section{Gambar 2. Nilai Standardize Estimate Model Fertilitas}

Gambar 2 merupakan path diagram model fertilitas yang ditunjukkan dengan nilai standardize-nya. Identifikasi model dilihat dari jumlah parameter yang diestimasi (t) sebanyak 4, dan jumlah varians-kovarians (s) sebesar 9 sehingga dikatakn bahwa model over identified karena nilai t kurang dari s.

Untuk kriteria kesesuaian model ditunjukkan pada Tabel 5.

Tabel 5. Kriteria Kebaikan Model Variabel Laten Fertilitas

\begin{tabular}{cccc}
\hline Kriteria & $\begin{array}{c}\text { Cutt-of } \\
\text { value }\end{array}$ & $\begin{array}{c}\text { Hasil } \\
\text { Model }\end{array}$ & $\begin{array}{c}\text { Evaluasi } \\
\text { model }\end{array}$ \\
\hline $\begin{array}{c}\text { Chi-Square } \\
(\mathrm{df}=3 ; 0,05)\end{array}$ & $\leq 5.991$ & 1.363 & Baik \\
P-value & $\geq 0.05$ & 0.506 & Baik \\
GFI & $\geq 0.90$ & 0.976 & Baik \\
RMSEA & $\leq 0.08$ & 0.00 & Baik \\
AGFI & $\geq 0.90$ & 0.880 & Kurang Baik \\
\hline
\end{tabular}

Tabel 6. Loading Factor Indikator Fertilitas

\begin{tabular}{cccc} 
Hubungan & Estimasi & $\boldsymbol{P}$-value & Keterangan \\
\hline X4 $\leftarrow$ & 0,925 & 0.440 & $\begin{array}{c}\text { Tidak } \\
\text { Signifikan }\end{array}$ \\
$\begin{array}{c}\text { Fertilitas } \\
\text { X3 } \leftarrow\end{array}$ & 0,900 & 0,001 & Signifikan \\
Fertilitas & & & \\
X2 $\leftarrow$ & 0,914 & 0.001 & Signifikan \\
Fertilitas & & & \\
X1 $\leftarrow$ & 0,822 & 0.001 & Signifikan \\
Fertilitas & & &
\end{tabular}

Kriteria kebaikan model variabel laten fertilitas pada Tabel 5 dapat diterima karena telah memenuhi setidaknya 4 kriteria kebaikan model yaitu Chi-Square, p-value, GFI, dan 
RMSEA. Berikutnya menguji tingkat signifikansi indikator yang merupakan validitas dari variabel latennya. Berikut hasil dari nilai loading faktor dan hasil pengujian signifikansi untuk masing-masing indiktor sebagaimana ditunjukkan pada Tabel 6

Berdasarkan Tabel 6 terlihat bahwa ada tiga indikator yang signifikan membentuk variabel laten fertilitas yaitu X1, X2 dan X3 . Hal ini ditunjukkan dari nilai $p$-value $<\alpha(0,05)$. Langkah berikutnya yaitu menguji reliabilitas construct reliability (CR) sebagaimana ditunjukkan pada Tabel 7.

Tabel 7. Perhitungan Construct Reliability Fertilitas

\begin{tabular}{ccc}
\hline Hubungan & Estimasi & $\begin{array}{c}\text { Kesalahan } \\
\text { pengukuran } \\
\left(\boldsymbol{e}_{\boldsymbol{i}}=\mathbf{1}-\boldsymbol{L i}^{\mathbf{2}}\right)\end{array}$ \\
\hline X4 $\leftarrow$ Fertilitas & 0,925 & 9,199 \\
$\mathrm{X} 3 \leftarrow$ Fertilitas & 0,900 & 8,945 \\
X2 $\leftarrow$ Fertilitas & 0,914 & 8,199 \\
X1 $\leftarrow$ Fertilitas & 0,822 & 7,049 \\
Jumlah & 3,561 & 33,392 \\
\hline
\end{tabular}

Berdasarkan Tabel 7 didapatkan hasil perhitungan nilai construct reliability sebagai berikut.

$$
\begin{aligned}
C R= & \frac{\left[\sum_{i=1}^{n} L_{i}\right]^{2}}{\left[\sum_{i=1}^{n} L_{i}\right]^{2}+\left[\sum_{i=1}^{n} L e_{2}\right]}, \\
& =\frac{[33,392]^{2}}{[33,392]^{2}+[3,561]} \\
& =0,9968
\end{aligned}
$$

Nilai construct reliability pada variabel laten fertilitas sebesar 0,9968. Nilai tersebut lebih dari 0.7 sehingga dapat dikatakan bahwa variabel laten fertilitas memiliki reliabilitas yang baik dan mampu menjelaskan secara representative terhadap variabelnya.

\section{Variabel Laten Mortalitas}

Analisis First Order CFA pada variabel laten mortalitas tersusun dari empat indikator yaitu $\mathrm{X}_{5}, \mathrm{X}_{6}, \mathrm{X}_{7}$, dan $\mathrm{X}_{8}$. Hasil pendugaan indikator mortalitas sebagaimana ditunjukkan pada Gambar 3.

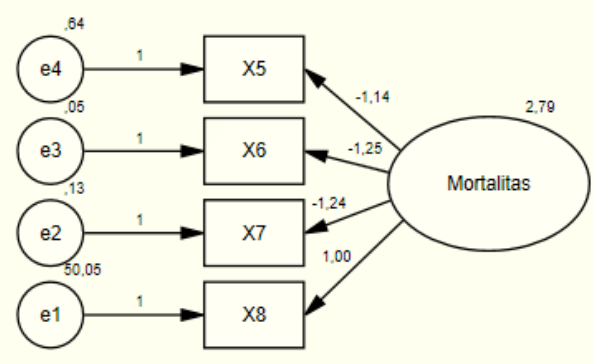

\section{Gambar 3. Nilai Standardize Estimate Model Mortalitas}

Gambar 3 menunjukkan path diagram model mortalitas dengan nilai standardize-nya, kemudian Langkah berikutnya yaitu mengidentifikasi model, dimana hasilnya ditunjukkan pada Tabel 8 berikut.

Tabel 8. Kriteria Kebaikan Model Variabel Laten Mortalitas

\begin{tabular}{cccc}
\hline Kriteria & $\begin{array}{c}\text { Cutt-of } \\
\text { value }\end{array}$ & $\begin{array}{c}\text { Hasil } \\
\text { Model }\end{array}$ & $\begin{array}{c}\text { Evaluasi } \\
\text { model }\end{array}$ \\
\hline $\begin{array}{c}\text { Chi-Square } \\
(\mathrm{df}=2 ; 0,05)\end{array}$ & $\leq 5.991$ & 1.374 & Baik \\
$P$-value & $\geq 0.05$ & 0.503 & Baik \\
GFI & $\geq 0.90$ & 0.975 & Baik \\
RMSEA & $\leq 0.08$ & 0.00 & Baik \\
AGFI & $\geq 0.90$ & 0.877 & Kurang Baik \\
\hline
\end{tabular}

Berdasarkan Tabel 8 menunjukkan bahwa variabel laten mortalitas telah memenuhi kriteria kebaikan model. Hal ini karena telah memenuhi 4 kriteria kebaikan model yaitu ChiSquare, p-value, GFI, dan RMSEA. Sehingga dapat dikatakan bahwa model variabel laten mortalitas dapat diterima.

Tabel 9. Loading Factor Indikator Mortalitas

\begin{tabular}{cccc}
\hline Hubungan & Estimasi & $\begin{array}{c}\boldsymbol{P} \text { - } \\
\text { value }\end{array}$ & Keterangan \\
\hline $\begin{array}{c}\text { X8 } \leftarrow \\
\text { Mortalitas } \\
\text { X7 } \leftarrow\end{array}$ & 0,925 & 0.223 & $\begin{array}{c}\text { Tidak } \\
\text { Signifikan }\end{array}$ \\
$\begin{array}{c}\text { Mortalitas } \\
\text { X6 } \leftarrow\end{array}$ & 0,900 & 0,001 & Signifikan \\
$\begin{array}{c}\text { Mortalitas } \\
\text { X5 } \leftarrow\end{array}$ & 0,914 & 0,001 & Signifikan \\
Mortalitas & 0,822 & 0,001 & Signifikan \\
\hline
\end{tabular}


Langkah berikutnya yaitu menguji signifikansi variabel indikator yang merupakan validitas terhadap variabel laten sebagaimana ditunjukkan pada Tabel 9. Tabel 9 menunjukkan bahwa terdapat tiga indikator yang signifikan yang telah membentuk variabel laten mortalitas yaitu X5, X6 dan X7. Hal ini dilihat dari nilai $p$-value yang kurang dari $\alpha(0,05)$.

Langkah berikutnya adalah menguji reliabilitas construct reliability dari variabel laten mortalitas. Hasil dari perhitungan $\mathrm{CR}$ variabel laten mortalitas sebagaimana ditunjukkan pada Tabel 10 berikut.

Tabel 10. Perhitungan Construct Reliability Mortalitas

\begin{tabular}{ccc}
\hline Hubungan & Estimasi & $\begin{array}{c}\text { Kesalahan } \\
\text { pengukuran } \\
\left(\boldsymbol{e}_{\boldsymbol{i}}=\mathbf{1}-\boldsymbol{L i}^{\mathbf{2}}\right)\end{array}$ \\
\hline $\begin{array}{c}\text { X8 } \leftarrow \\
\text { Mortalitas } \\
\text { X7 } \leftarrow\end{array}$ & 0,925 & 6,743 \\
$\begin{array}{c}\text { Mortalitas } \\
\text { X6 } \leftarrow\end{array}$ & 0,900 & 6,743 \\
$\begin{array}{c}\text { Mortalitas } \\
\text { X5 } \leftarrow\end{array}$ & 0,914 & $-6,743$ \\
$\begin{array}{c}\text { Mortalitas } \\
\text { Jumlah }\end{array}$ & 0,822 & 6,245 \\
\hline
\end{tabular}

Berdasarkan Tabel 10 didapatkan hasil perhitungan nilai construct reliability sebagai berikut :

$$
\begin{aligned}
C R=\frac{\left[\sum_{i=1}^{n} L_{i}\right]^{2}}{\left[\sum_{i=1}^{n} L_{i}\right]^{2}+\left[\sum_{i=1}^{n} L e_{2}\right]}, \\
=\frac{[12,988]^{2}}{[12,988]^{2}+[3,561]} \\
=0,979
\end{aligned}
$$

Nilai construct reliability variabel laten mortalitas sebesar 0,979. Sehingga dapat dikatakan bahwa variabel laten mortalitas mampu menjelaskan secara representative dan konsisten terhadap variabelnya.

\section{Variabel Laten Migrasi}

Analisis First Order CFA pada variabel laten migrasi terdiri dari tiga indikator yaitu $\mathrm{X}_{10}, \mathrm{X}_{11}$, dan $X_{12}$. Hasil pendugaan indikator migrasi sebagaimana ditunjukkan pada Gambar 4 berikut.

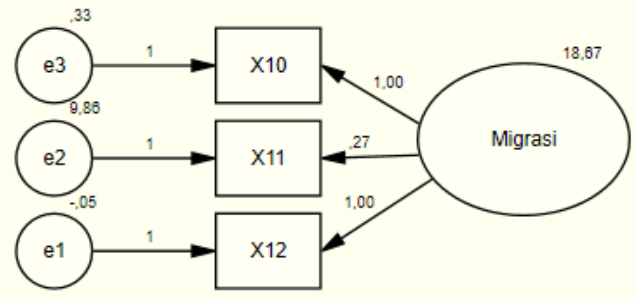

\section{Gambar 4. Nilai Standardize Estimate Model Migrasi}

Gambar 4 menunjukkan path diagram model migrasi dengan nilai standardize-nya. Langkah selanjutnya yaitu melakukan identifikasi model dengana menggunakan model over identified. Hal ini dapat dilihat dari jumlah parameter yang diestimasi (t) sebanyak 6, sedangkan jumlah varians-kovarians antara variabel manifest (s) sebanyak 8. Untuk identifikasi model variabel laten migrasi ditunjukkan pada Tabel 11 berikut.

Tabel 11. Kriteria Kebaikan Model Variabel Laten Migrasi

\begin{tabular}{cccc}
\hline Kriteria & $\begin{array}{c}\text { Cutt-of } \\
\text { value }\end{array}$ & $\begin{array}{c}\text { Hasil } \\
\text { Model }\end{array}$ & $\begin{array}{c}\text { Evaluasi } \\
\text { model }\end{array}$ \\
\hline $\begin{array}{c}\text { Chi-Square } \\
(\mathrm{df}=1 ; 0,05)\end{array}$ & $\leq 3.84$ & 13.681 & $\begin{array}{c}\text { Kurang } \\
\text { Baik }\end{array}$ \\
$\begin{array}{c}\text { P-value } \\
\text { Kaik }\end{array}$ & $\geq 0.05$ & 0.000 & $\begin{array}{c}\text { Kurang } \\
\text { Baik }\end{array}$ \\
GFI & $\geq 0.90$ & 0.791 & $\begin{array}{c}\text { Kurang Baik } \\
\text { RMSEA }\end{array}$ \\
AGFI & $\geq 0.08$ & 0.685 & $\begin{array}{c}\text { Baik } \\
\text { Kurang Baik }\end{array}$ \\
\hline
\end{tabular}

Kriteria kebaikan model variabel laten migrasi sebagaimana ditunjukkan pada Tabel 11 telah memenuhi kriteria kebaikan model yakni berdasarkan kriteria RMSEA. Hal ini dapat dikatakan bahwa model dapat diterima.

Langkah selanjutnya yaitu menguji signifikansi variabel indikator yang merupakan validitas terhadap variabel laten sebagaimana ditunjukkan pada Tabel 12.

Berdasarkan Tabel 12 dapat dilihat bahwa ada dua indikator yang signifikan membentuk variabel laten migrasi yaitu X11 dan X12. Hal ini dilihat dari nilai $p$-value $<\alpha$ $(0,05)$. 
Tabel 12. Loading Factor Indikator Migrasi

\begin{tabular}{cccc}
\hline Hubungan & Estimasi & $\begin{array}{c}\boldsymbol{P} \text { - } \\
\text { value }\end{array}$ & Keterangan \\
\hline $\begin{array}{c}\text { X12 } \leftarrow \\
\text { Migrasi }\end{array}$ & 0.786 & 0.223 & $\begin{array}{c}\text { Tidak } \\
\text { Signifikan }\end{array}$ \\
$\begin{array}{c}\text { X11 } \leftarrow \\
\text { Migrasi }\end{array}$ & 0.589 & 0.001 & Signifikan \\
$\begin{array}{c}\text { X10 } \leftarrow \\
\text { Migrasi }\end{array}$ & 0,518 & 0.001 & Signifikan \\
\hline
\end{tabular}

Tahap berikutnya yaitu menguji construct reliability (CR) sebagaimana ditunjukkan pada Tabel 13 berikut.

Tabel 13. Perhitungan Construct Reliability Migrasi

\begin{tabular}{ccc}
\hline Hubungan & Estimasi & $\begin{array}{c}\text { Kesalahan } \\
\text { pengukuran } \\
\left(e_{i}=1-L i^{2}\right)\end{array}$ \\
\hline $\begin{array}{c}\text { X10 } \leftarrow \\
\text { Mortalitas } \\
\text { X11 } \leftarrow\end{array}$ & 0,786 & 7,915 \\
$\begin{array}{c}\text { Mortalitas } \\
\text { X12 } \leftarrow\end{array}$ & 0,589 & 5,718 \\
Mortalitas & 0,518 & $-5,475$ \\
Jumlah & 1,893 & 5,713 \\
\hline
\end{tabular}

Berdasarkan Tabel 13 hasil perhitungan nilai construct reliability untuk variabel laten migrasi adalah sebagai berikut :

$$
\begin{aligned}
C R=\frac{\left[\sum_{i=1}^{n} L_{i}\right]^{2}}{\left[\sum_{i=1}^{n} L_{i}\right]^{2}+\left[\sum_{i=1}^{n} L e_{2}\right]}, \\
=\frac{[5,713]^{2}}{[5,713]^{2}+[1,893]} \\
=0,945
\end{aligned}
$$

Nilai construct reliability variabel laten migrasi sebesar 0,945 , sehingga variabel laten migrasi dapat dikatakan memiliki reliabilitas yang baik dan mampu menjelaskan secara representative setiap variabelnya

\section{Penutup}

Berdasarkan hasil analisis dari data pertumbuhan penduduk di Kecamatankecamatan yang ada di Kabupaten Bojonegoro pada tahun 2018, diperoleh kesimpulan sebagai berikut.

a. Karakteristik pertumbuhan penduduk di Kabupaten Bojonegoro pada tahun 2018 dipengaruhi oleh tiga variabel laten diantaranya yaitu fertilitas, mortalitas, dan migrasi, sementara setiap variabel laten terdapat beberapa indikator yaitu variabel laten fertilitas meliputi empat indikator diantaranya yaitu jumlah kelahiran total, angka lahir hidup, rasio anak wanita, dan angka prevelensi pemakaian kontrasepsi, kemudian variabel laten mortalitas meliputi empat indikator diantaranya yaitu angka harapan hidup, angka kematian bayi, angka kematian balita, dan maternal mortality, kemudian variabel laten yang terakhir yaitu variabel laten migrasi meliputi empat indikator diantaranya migrasi masuk, migrasi keluar, migrasi neto, dan migrasi bruto.

b. Dari kedua belas indikator yang terdapat dalam variabel laten, diketahui bahwa yang paling dominan terdapat dalam variabel laten fertilitas berupa indikator jumlah kelahiran total $\left(\mathrm{X}_{1}\right)$, angka lahir hidup $\left(\mathrm{X}_{2}\right)$, rasio anak wanita $\left(\mathrm{X}_{3}\right)$, sedangkan dalam variabel laten mortalitas berupa indikator angka harapan hidup $\left(\mathrm{X}_{5}\right)$, angka kematian bayi $\left(\mathrm{X}_{6}\right)$, angka angka kematian balita $\left(\mathrm{X}_{7}\right)$, sedangkan dalam variabel laten migrasi berupa indikator migrasi keluar $\left(\mathrm{X}_{10}\right)$, dan migrasi bruto $\left(\mathrm{X}_{12}\right)$, sedangkan indikator yang tidak dominan dalam mempengaruhi pertumbuhan penduduk di Kabupaten Bojonegoro adalah angka prevelensi pemakaian kontrasepsi $\left(\mathrm{X}_{4}\right)$, maternal mortality $\left(\mathrm{X}_{8}\right)$, migrasi neto $\left(\mathrm{X}_{11}\right)$.

\section{Referensi}

[1] Prawiro, Ruslan, H. Kependudukan, Teori, Fakta dan Masalah, Penerbit Liberty, Yogyakarta. (2000).

[2] Hasibuan, M.S.P. Ekonomi Pembangunan dan Pembangunan Indonesia. CV. Armico, Bandung. (2002).

[3] BPS Kabupaten Bojonegoro. Kabupaten Bojonegoro Dalam Angka Tahun 2018. Bojonegoro: BPS Kabupaten Bojonegoro. (2018).

[4] Brown, A. T. Confirmatory Factor Analysis for Applied Research. New York: The Guilford Press. (2006). 
[5] William, Jr., C. Black, Barry J. Ba Joseph F. Hair. Multivariate Data Analysis- Pearson Education Limited. (2013)

[6] Dinas Kesehatan Bojonegoro. Profil Kesehatan Kabupaten Bojonegoro Dalam Angka Tahun 2018. Bojonegoro: Dinas Kesehatan Kabupaten Bojonegoro. (2018).

[7] Lee, S. Y. Structural Equation Modeling A Bayesian Approach. John Wiley \& Sons, Ltd. (2007).
[8] Mardia, K. V. Applications of some measure of multivariate skewness and kurtosis in testing normality and robustness studies. Sankhya, Series B, 36 , 115-128. (1974).

[9] Khine, M. S., Centre, S. a., \& Curtin University, P. A. Application Of Structural Equation Modeling In Educational Research And Practice. Netherlands: Sense Publishers. (2013). 